\title{
Educating a Dying Person under the Framework of Hindu- Testaments Series-I
}

\author{
Dr. Kumari Vineeta \\ Faculty of Education, S.M. College, T.M. Bhagalpur University, Bhagalpur, India
}

\begin{abstract}
My findings revolvesaround the epicenter of Hinduism and its wisdom based on scriptures, right from origin of Hinduism that describes two living God Rama and Krishna between 1000 \& 2000 BC they have directly communicated what is righteousness and non-righteousness (Dharma \& Adharma) the soul condition for sanctioning moksha (exemption from the cycle of rebirth) in the context of dying person. They have proclaimed to be the sole protector and responsible for establishing righteousness by taking birth on earth as and when needed and manifest myself in countless form and have proclaimed the indestructibility of soul. The desire to live or the fear of death neither effects the body nor the soul at the time of death one has to face bodily pain and mental suffering. Bodily pain originates from physical body and mental suffering comes from mind.An occult one experiences bodily pain but not at all mental one as they have linked their faith in God. I have described the happening from Hindu testaments compiled by Indian sage like Balmiki, Ashtabakra, Vyasa and others. For a mortal body no option is left but to die then why should we daunt of death, the body has to die either way with or without fear they why not we depart cheerfully visualising God's image in mind disconnecting all existing relations telling good bye to them with a promise to come back in the form of some new body if God denied to grant Moksha. Don't keep tears on face, kill your grief with your intelligence and bear yourself up with the strength your own self.

Keywords: daunt,moksha (exemption from rebirth cycle), righteousness (Dharma), consciousness, sheer,occultist
\end{abstract}

\section{Introduction}

As a university teacher educator either in class room or in a seminar, frequently I have to encountered with very common query like what is after death? Why people daunt from death? What is life after death? Where we go after death?Etc. As I am from an orthodox Brahmin family, I have heard so many stories from Hindu scriptures like Bhagwatpuran, Garurpuran and most popular Bhagwat Gita a direct version of God Krishna. So I confined my finding in this paper only to Hindu testaments \& wisdom. Prime aspect of the investigation was to educate a person who is on death bed expecting death at any moment.Such person (mostly not all) has only desire that a miracle will happens and will get rid of the jaw of death, but such desiresare not at all possible to be full filled. There are some stories in Hindu scriptures as in a very famous epic Ramayana when King of Monkeys Bali was killed by Rama whohiding himself from the vision of Bali and when God Rama offered him to save from death he refused to accept the offer of God Rama. SimilarlyRavana, Meghnad and others prefer to die before God in anticipation to get Moksha means liberation from the cycle of birth or of samsara they all preferred death than life.

However, there are various evidences in Hindu testaments about the immortality of seven people of those days.

\section{Discussion}

Now there are two or three approaches to this question of life after death. As we are aware, there is thought in process, there is a belief that this life on earth is all that is to be: there is nothing before, there is nothing after. If you are fortunate to be a beneficiary of certain circumstances, you will get a nice future at some date in the history of the universe. There is another approach which admits that there are supra-terrestrial worlds and depending upon how you behave yourselves here, the world where you have to go is decided. This world is only a preparatory stage to a more permanent life elsewhere, and it is right that you should do good things, acquire Dharma, (merit) so that a happier life above is reserved for you as told by Kautilya in his philosophy. It means for dying person Dharma is the only friend.

VidyamitrampravasheshuBharyamitramgriheshuca|

Byadhitasyaaushadhimitram, Dharmomitrammritasyacal|

I belong to a tradition which believes somewhat differently. We believe that the fundamental reality of life is a consciousness. There is a consciousness that is manifest in the universe in a million forms. One consciousness throwing itself into myriad forms, organising itself at different levels of creation in different 
ways, and this consciousness at its core is Divine. Everything that exists on earth is instinct with this element of consciousness. Time was when we thought that only human beings have consciousness and the beginnings of consciousness, perhaps, are to be found in certain animals. It was given, as we know, to an Indian Scientist, Sir Jagadish Chandra Bose (1857 - 1937) a leading scientist and first Indian to demonstrate with the aid of specially developed instruments how there is a consciousness, sensitivity even in plants, which respond to stimuli from outside. Further experiments have been carried out, and the probing of the scientists confirm the perception of the Indian seers that this existence or the presence of consciousness does not stop at the level of the plant but it goes down even to the metal level, even to the stone level. That is, even in a particle of matter there is a speck of consciousness. And the meaning of life, according to our tradition, is a spiritual evolution of consciousness. This speck of consciousness, instinct in every particle of stone or metal evolves gradually. And how does it evolve?

At this stage when this element enters the physical body, it becomes an entity. It is no more a speck, no more an element; it develops into an entity and this entity that in-dwells the human body, as it develops, is called the soul. So each human body has a soul, and this soul is potentially divine. There is at its core a divine, indestructible element. It is this immortal element which makes the soul survives. The soul takes birth in order to grow. It grows on the experience that it gathers from life to life. It assimilates the essence of each experience and puts on a stature, develops itself.

\author{
Avinaashitu tad viddhiyenasarvamidamtatam; \\ Vinaashamavyayasyaasyanakashchitkartumarhati. (B. Gita 2.17) \\ väsäàsijérëäniyathävihäyanavänigåhëätinaro 'paräëi \\ tathäçaréräëivihäyajérëänyanyänisaàyätinavänidehé (B. Gita 2.22) \\ nainaàchindantiçasträëinainaàdahatipävakaù \\ nacainaàkledayantyäponaçoñayatimärutaù (B. Gita 2.23)
}

Now what will happens when the time has come for the physical body to be shed? That is what you mean by death after all: this body ceases to live. According to our perception, the time of departure comes when the soul decides to leaveand it leaves when it finds it cannot grow further in the present body or for whatever reason. Normally it is the soul that takes the decision to leave the body.

At the moment of death the soul casts a look back, gathers the highlights of experience in which it expressed some divine qualities that it carries with it, assimilates them, decides what kind of experience it is going to have in the next birth, and then it leaves the body. It is when the soul leaves the body that the body becomes lifeless, and we say the man is dead. Actually he has only cast away his outermost physical sheath. Usually at the moment of death he is unconscious and then he wakes up minus the physical body with all the remaining four sheaths intact in quite another world, what we call the Sukshmaloka- the subtle physical world, which is a prototype of our physical world here. All movements, all imaginations and ideas and ideals on earth stand organised here in a perfect pattern. It is a world of harmony, it is a world of beauty, where all inspirations, all impulsions of beautiful movements in life may issue. Only, when they get deflected in the transition we have broken results on earth.

Now, when the person wakes up there, he tries to find his body, but he finds there is no physical body. It takes a little time for the departed to become aware that the physical body is no longer there; he finds himself in a world that is a perfect replica of the life that he has lived on earth. Ifhe lived a life of beauty, of goodness, kindness, thought of fine things, noble things, he finds himself surrounded by beautiful, harmonious surroundings, and that is really the heaven. If the person has led a dark life, doing ill, thinking evil, perpetrating falsehoods and cunning, he finds himself in a replica world which is darks, uncongenial, and that is the hell. Heaven and hell are not geographical locations somewhere in the universe; Ref. B Gita-11.20.

\title{
Amee hi twaamsurasanghaahvishantiKechidbheetaahpraanjalayogrinanti; SwasteetyuktwaamaharshisiddhasanghaahStuvantitwaamstutibhihpushkalaabhih
}

But they are states of your own consciousness, projections of the life you lead while on earth. The thoughts that you think, the feelings that you entertain, the actions that you do- all are projected there, and you find yourself in surroundings which truly a projection of your life on earth. It is thus that each one of us carries our hell or heaven with ourselves. As here, so there; as there, so here.

Frequently,we use to read in newspapers about the people suddenly come back after death within four years, two years, six months of their departure giving horrid details about their past connections- a child claiming to be the husband of so-and-so and showing the houses and streets in which he had lived? Well, these are aberrations; these deaths are somewhat sudden, when the soul is really not prepared to leave the body. Somehow death takes place, maybe due to some accident, maybe due to wrong diagnosis of illness or whatever. But the soul is still attached to the earth. So it does not go at all beyond the earth zone. It comes back, and 
because the soul has not crossed over and shed its sheaths, not had sufficient rest, a period of assimilation, all the past memories are fresh. Now this is a very unnatural thing. It is a thing that should be frowned upon. It should be discouraged, not cherished as something wonderful. If any child shows signs of past memory, it has to be ignored and discouraged.

I was mentioning about the soul and its place of rest. It is helped by benevolent agencies in those higher worlds to prepare itself and according to the choice it has made, it selects its environment, the particular womb which would be most favourable to it to take birth. An occultists say it see a point of light glistening and there it goes and hovers around it. Very often the soul does not enter till a body is born [Isavasyopanisad: 11]. After the body is born the soul gradually asserts its influence and then gets into the body.

Vidyāmc'āvidyām cay as tad ved'obhayamsaha avidyayāmrtyumtírtvāvidyayā' mŗtamaśnute \|

He who understands vidyā and avidyā, both together, attains' to the ture of immortals through vidyā (knowledge of ritualistic philosophy), having conquered death by avidyā (pure rituals).

When the soul departs our body after our death,this soul, according to what I heard, is having both life as well as a mind. Now when the body is dead, the death occurs because the body is no more able to respire oxygen. Now this life, which is a vital energy, cannot be without a body to respire. So the soul which I mention cannot be a life because that has no body to breathe.

Secondly, the consciousness is prior. Consciousness is not an epiphenomenon of the body. The brain is only an instrument of consciousness. Consciousness is not confined to any part of the body-not in the heart alone, not in the mind alone, but if pervading the whole body, the body has a consciousness. The life-part has a consciousness, the heart has a consciousness, my limbs have a consciousness, and the whole science of the culture of consciousness is today awakening to the fact that consciousness can dispense with the body and still function and produces results. So the maintenance or the rejection of a physical body does not affect the tenure of consciousness. Consciousness is different from the mind as the mind is only a projection, a particular formation, an organisation of consciousness for the purpose of thought-activity, ideational activity, even as the same consciousness organises itself in the heart, the heart of emotions where it expresses itself in movements of love, in movements of harmony. Consciousness is all-pervading and the body is its instrument.

\section{Ö̇purṇamadaḥpūrṇamidaìnūrṇātpūrṇamudacyate Pūrṇasyapūrnamāidàyapūrnamev' āvaśișyate Om śāntiḥśāntiḥśāntih \|}

The invisible is the infinite; the visible too is the infinite, from infinite the visible universe of infinite extension has come out. The infinite remains the same, even though the infinite universe has come out of it. The mechanical aspect is the sum total of energy. Energy can neither be created nor destroyed its form can change from one form to another, but it will not disappear, because "It" remains constant. [Bhagwat Gita: 2.23]

\section{Acchedyo'yamadaahyo'yamakledyo'shoshyaeva cha; Nityahsarvagatahsthaanurachalo'yamsanaatanah}

So the key to our approach is in the recognition of consciousness as a pervading reality, matter, mind, sperm, they are instrumental bodies, sheaths, which do not determine the life of the consciousness. What is consciousness after all? It is a radiation of the soul. It continues to develop.

Now I should say that we have to educate the society, create that civic consciousness of our people that with the parts of the dead body some real service can be done for others who are still living, and it must be a gift of free choice, an enlightened gift, to donate the eyes or the heart or whatever it is, and then they can certainly cremate the rest.

Occultists are of the opinion that to bury the body fits in more with the economy of nature, because as the disintegration proceeds, the physical substance gets absorbed in universal matter. But if you burn, it is quite differentno doubt ultimately even that is absorbed on earth but not in that form. So there is a rethinking on the subject of cremation everywhere, though it looks to be a most convenient way of disposing of a dead body.

Cremation in itself is rather a drastic way out [Isavasyopanisad: 17].

Vāyuvanilamamrtamath'edambhasm 'āntamsaríram |

Om krato samara krtamsmarakrtosmarakrtamsmara \| 
As the course of the departing soul entirely depends upon the predominant thoughts at the dying moment, the devotee is at the time of death asking to mind to fill itself with the memories of all the good deeds of his life so that Moksha may be granted [B. Gita: 8.6]

\section{Tasmaatsarveshukaaleshumaamanusmarayudhya cha; Mayyarpitamanobuddhirmaamevaishyasyasamshayam.}

In factwe know nothing about death. Every night we are dying in a way and coming alive in the morning. We are dying because what has already happened to us is gone forever? Psychologically, we are dead to what happened to us yesterday,the actual event is finished, but carrying it as burden, and nursing it carefully for years going from dimension to another is also dying.

The process of ascension is death of old values. When the human being comes to understand that at some moment or the other all his worldly activity will cease, and he says 'let me think that all this has already ceased. Then how would I lead my life? What would I clear up?' 'Yesterday is dead - forget it! Tomorrow has not come, don't worry! Today is here, use it! 'Om kratosmarakrtamsmarakratosmarakrtamsmara - 'Remember, remember, remember.'

\section{Conclusion}

My entire discussion is focused on Hindu scriptures right from the beginning of Hindu theory of time cycles which has four different yugas a time subdivision scale in Hindu mythology like 1. The Satya or Krita Yuga, a Golden Age, 2. The Treta Yuga, the age of Ritual, 3. Dvapara Yuga, the age of doubt: Man loses the sense of the divine reality of the world and grows away from natural law, 4. The Kali Yuga; the age of conflict and confusion began in $3012 \mathrm{BC}$ and will end with the nearly total devastation of the present humanity. All references were of the above noted period giving which sage Valmiki and Vyasa were the main authors of the testaments like Ramayana, Mahabharata and B.Gitaetc andaccording to historical evidence between 1000 and 2000 BC were happens to be the period of completion. Out of which all the 700 verses of B.Gita has directly pronounced by God Krishna. Robert Oppenheimer in 16 July 1945 the pioneer of the atomic explosion was also of the concurrent opinion on Hindu wisdom time scale by recognising Gita 11.32

\section{Kālo 'smilokaksayakrtpravrddho, lokānsamāhartumihapravrttah} Rtepitvāmnabhavisyantisarve, yevasthitāhpratyaníkesuyodhāh

Here Kala is the Sanskrit word meaning long time.

For a dying person his desire is at the root of all sufferings of this world as Gita says reference chapter 2(13).

\section{Maatraasparshaastukaunteyasheetoshnasukhaduhkhadaah; Aagamaapaayino'nityaastaamstitikshaswabhaarata.}

$5.22]$.

If for a person there is no desire for material world,then theirpain and pleasure both are same [B.Gita

$$
\begin{aligned}
& \text { Shaknoteehaiva yah sodhumpraakshareeravimokshanaat; } \\
& \text { Kaamakrodhodbhavamvegamsayuktahsasukheenarah. }
\end{aligned}
$$

Whereas once a person rises above pain and pleasure and attains Moksha. When we are sure that all desire can never be full filled to any one and that everyone being born has to die. Obviously why we desire to live and why we fear of death. Hence be bold and discard desire.One of the great scholar of Treta Yuga Ashtabakra reference 14(2) narrated when desires is ceased of we maynot permit to alive more. The indestructivity of Aatma as referred in B.Gita 2.23is also supported by Ashtabakra Gita chapter 2(11). So far the quality of Aatma is concerned it is eternal andindestructive.

As the physical dimension of Aatmais concerned there appears to be a varying parameters but every Hindu testament shows that the dimension of Aatma is invisible part of the body which transfer itself during death moment. According to Kathopnishad 2(12 - 13) where this soul is described as $1 \times 10^{-4}$ of the upper portion of the hair point in size. The 'SvetasvatraUpnishad (5.9) confirms this

$$
\begin{aligned}
& \text { bālāgra-śata-bhāgasya, śatadhākalpitasyaca } \\
& \text { bhāgojívahvijńneyah, sacānantyāyakalpate }
\end{aligned}
$$


Showsspirit soul is $10^{-8}$ of the upper part of the hair dimension but in the MundakaUpnishad 3.1.9 the measurement of the soul is accepted as the atomic size through this verse

$$
\begin{aligned}
& \text { eso 'nurātmācetasāveditavyoyasminprānahpańcadhāsamiviveśa } \\
& \text { prānaiścittaḿsarvamotaḿmrajānāmyasminviśuddhevibhavatyesaātmā }
\end{aligned}
$$

Hence its functioning is to be realised never to be visualised, and finally depart for the unprecedented journey keeping in mind the sloka of B.Gita (8.10).

On summarizing the findings I find that if someone afraid of death even then the body shall die and even without fear it shall also die so recall faith in God, faith in your good righteousness and be ready to live this materialistic world. The well-wishers, the relatives, the friends, the foe must not express grief for the departing soul at the departing moment as advised in Garurpuran chapter 8(9).

\section{Rogino-anti-kamasadhyashochniyamnabandhwah| \\ Samarneeyampavitram me naamdheyammuhurmuhuh\|}

In my next communication the thrust area will focus on same topics under non-Hindu testaments and latest scientific findings.

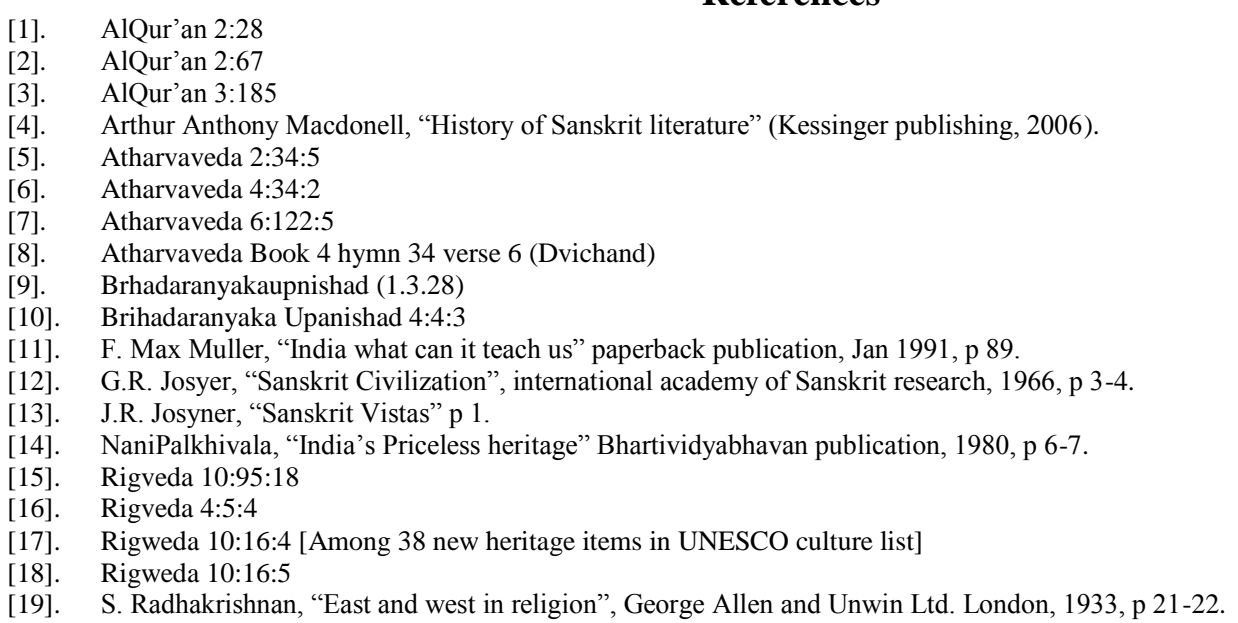

